\title{
Modifikasi Pembelajaran PPDS-1 Ilmu Bedah Fakultas Kedokteran Universitas Udayana dalam Masa Pandemi COVID-19
}

\section{Ketut Wiargitha}

Koordinator Program Studi Ilmu Bedah Fakultas Kedokteran Universitas Udayana/RSUP Sanglah Denpasar.

*Penulis korespondensi: kwiargitha@yahoo.co.id.

DOI: https://doi.org/10.24843/JBN.2020.v04.is01.p02

Pada 31 Desember 2019, WHO (World Health Organization) China Country Office melaporkan kasus pneumonia yang tidak diketahui etiologinya di Kota Wuhan, Provinsi Hubei, Cina. Pada tanggal 7 Januari 2020, telah ditemukan pneumonia tersebut merupakan jenis baru coronavirus (coronavirus disease, COVID-19). ${ }^{1}$

Pada tanggal 30 Januari 2020 WHO telah menetapkan sebagai kedaruratan kesehatan masyarakat yang meresahkan dunia / public health emergency of international concern (KKMMD/PHEIC). Penambahan jumlah kasus COVID-19 berlangsung cukup cepat dan sudah terjadi penyebaran antar negara. ${ }^{1}$

Penyakit coronavirus baru (COVID-19) yaitu disebabkan oleh coronavirus sindrom pernafasan akut yang parah (SARS-CoV-2) telah menyebar ke banyak negara, termasuk Indonesia. Wabah dimulai pada awal Maret 2020 dan hanya dalam waktu kurang dari sebulan telah terinfeksi 1.285 pasien dan 114 kematian di Indonesia sampai dengan 30 Maret 2020. ${ }^{2}$

Tidak hanya mengambil banyak nyawa pasien, tetapi juga teman sejawat sebagai penyedia layanan kesehatan. Atas nama tenaga pengajar dan peserta didik Program Pendidikan Dokter Spesialis (PPDS)-1 Ilmu Bedah Fakultas Kedokteran Universitas Udayana-RSUP Sanglah Denpasar, menyampaikan belasungkawa terdalam kepada semua pasien dan terutama kepada dokter, perawat, dan semua tenaga kesehatan yang tidak bisa bertahan dalam pertempuran melawan virus ini.

Melihat seriusnya penyakit ini, diperkirakan bahwa situasi ini akan memberikan perubahan besar pada manajemen tata laksana pasien khususnya di bidang bedah, dan sayangnya itu terjadi di tengah upaya untuk meningkatkan manajemen tata laksana untuk pasien-pasien bidang bedah di Indonesia. Ini akan menjadi waktu yang sulit, tetapi harus siap untuk mengatasi krisis COVID-19 di bidang bedah.

Berkenaan dengan peserta yang sedang mengikuti Program Pendidikan Dokter Spesialis, tentu membutuhkan pertimbangan dalam menentukan modifikasi pembelajaran yang tepat di tengah situasi pandemik saat ini. Berdasarkan surat Instruksi Rektor Universitas Udayana Nomor I tahun 2020, tentang Pencegahan Perkembangan dan Penyebaran Corona Virus Disease (COVID19) di Universitas Udayana, ${ }^{3}$ yaitu untuk melaksanakan instruksi sebagai berikut:

1. Pembelajaran di dalam dan luar kelas dalam bentuk tatap muka dengan peserta lebih dari 20 (dua puluh) dapat diganti menggunakan aplikasi pembelajaran jarak jauh (PJJ), email, WhatsApp, google classroom, dan lain-lain.

2. Pembelajaran di dalam dan luar kelas dalam bentuk tatap muka dengan peserta kurang dari 20 orang dapat dilaksanakan 
dengan memperhatikan dan mematuhi seluruh persyaratan Protokol di Area Institusi Pendidikan mengacu pada Surat Edaran Menteri Kesehatan RI Nomor HK.02.01/MENKES/199/2020 Tentang Komunikasi Penanganan Corona Virus Disease (COVID-19), ${ }^{4}$ yaitu: memastikan kebersihan ruang kuliah, ketersediaan sarana cuci tangan, melakukan skrining suhu badan, dosen dan mahasiswa tidak sedang menderita flu, dan menghindarkan kontak fisik dan pertukaran peralatan.

3. Pembelajaran praktikum ditunda atau digantikan dengan bentuk kegiatan penugasan lain yang setara dengan media online.

4. Seminar hasil penelitian Tesis dan Disertasi dapat dilaksanakan dengan peserta seminar paling banyak 20 orang dengan ketentuan peneliti, penguji, dan peserta seminar harus dalam keadaan sehat dan memenuhi Protokol di Area Institusi Pendidikan mengacu pada Surat Edaran Menteri Kesehatan RI Nomor HK.02.01/MENKES/199/2020. ${ }^{4}$

5. Dosen dan Tenaga Kependidikan dianjurkan untuk tidak menerima tamu, baik dari dalam maupun luar negeri dan sebaliknya, Dosen dan Tenaga Kependidikan dianjurkan untuk tidak kunjungan ke daerah lain di dalam dan ke luar negeri.

6. Mahasiswa asing yang sedang mengikuti program internasional yang sedang berlangsung, mengharuskan untuk kembali ke negara asalnya, agar diijinkan dan difasilitasi oleh KUI dan Pengelola Program Internasional. Serta untuk program yang akan berlangsung agar ditunda.

7. Rapat kelembagaan Universitas yang melibatkan peserta kurang dari 20 orang tetap dapat dilaksanakan. Pimpinan / koordinator / sekretaris rapat juga dapat mengkoordinasikan dengan peserta rapat untuk dilaksanakan secara online.

Menindaklanjuti Instruksi Rektor Universitas Udayana Nomor I tahun 2020, tentang Pencegahan Perkembangan dan Penyebaran Corona Virus Disease (COVID19) di Universitas Udayana $^{3}$ dan Rapat Koordinasi antara Rektor Universitas Udayana (UNUD), Wakil Rektor Bidang Akademik UNUD, Unit Sumber Daya Informasi (USDI) dan Lembaga Pengembangan Pembelajaran dan Penjaminan Mutu (LP3M) ${ }^{5}$ maka diambil langkah-langkah teknis untuk melaksanakan PJJ selama masa pencegahan perkembangan dan penyebaran Corona Virus Disease:

1. Pelaksanaan tatap muka diganti dengan tatap muka sinkron maya melalui Video Conference menggunakan sistem Webex Unud (https://universitasudayana.webex.com).

2. Pelaksanaan Belajar Mandiri maupun Tugas Terstruktur bisa dilakukan melalui portal E-Learning Universitas Udayana yaitu OASE Unud (https://oase.unud.ac.id)

3. Untuk dosen pengguna OASE UNUD namun bukan untuk perkuliahan reguler misalnya mengajar kelas internasional untuk mahasiswa asing, silakan menghubungi UPIKS unit anda untuk registrasi mata kuliah dan mahasiswa. Kelas dan mahasiswa akan dibuatkan oleh UPIKS melalui koordinasi dengan USDI.

Selain itu, Universitas Udayana menindaklanjuti surat edaran kementerian Pendidikan dan Kebudayaan Nomor 3 Tahun 2020 tentang Pencegahan Corona Virus Disease (COVID-19) pada Satuan Pendidikan dan Instruksi Rektor Nomor 1 Tahun 2020 tentang Pencegahan Perkembangan dan Penyebaran Corona Virus 
Disease (COVID-19) di Universitas Udayana serta menindaklanjuti hasil Rapat Pimpinan Universitas Udayana tanggal 18 Maret 2020, maka pimpinan Universitas Udayana memberikan kebijakan sebagai berikut untuk dilaksanakan yaitu ${ }^{6}$ :

1. Tenaga kependidikan diperkenankan untuk bekerja dari rumah tanpa mengurangi kinerja, tidak mempengaruhi hak-hak kepegawaiannya.

2. Pimpinan dari setiap unit kerja diharuskan membuat pembagian penugasan secara bergiliran, kecuali bagi unit kerja yang mempunyai jadwal shift dan atau mereka yang mendapatkan tugas khusus agar dapat disesuaikan dengan kebutuhan unit kerja.

Mengacu pada beberapa pertimbangan di atas, diterbitkan Surat Instruksi Dekan Fakultas Kedokteran Universitas Udayana Nomor B/25/UN 14.2.2/PK.01.03/2020 yang ditujukan untuk para Koordinator Program Studi Pendidikan Dokter Spesialis dan para Ketua Departemen di RSUP Sanglah, yaitu ${ }^{7}$ :

1. Mendukung pelayanan di RSUP Sanglah dengan sebaik-baiknya dan berkoordinasi dengan manajemen RSUP Sanglah agar pelayanan yang dilakukan oleh DPJP, residen, dan petugas lainnya menggunakan APD sesuai standar.

2. Menarik seluruh residen stase luar untuk memperkuat SDM pelayanan terhitung mulai tanggal surat ini diterbitkan.

3. Menunda semua penugasan residen stase luar, sampai batas waktu yang ditentukan kemudian.

4. Mengatur distribusi tugas DPJP dan residen sesuai kebutuhan di masingmasing tempat pelayanan.

5. Mengistirahatkan residen dan DPJP yang sakit/terduga pernah kontak kasus COVID-19 (self isolation) di rumah selama 14 hari.
6. Meniadakan visit besar, laporan jaga dan semua kegiatan akademik yang melibatkan banyak orang.

7. Menyarankan untuk membawa bekal makanan sehat dari rumah untuk kebutuhan sehari-hari.

8. Tetap melaksanakan pola hidup bersih dan sehat, menjaga kesehatan diri, keluarga, teman sejawat, dan masyarakat.

Sehubungan dengan dinyatakannya positif corona pada satu peserta didik Program Studi Bedah Toraks Kardiovaskuler (BTKV) Fakultas Kedokteran Universitas Airlangga Surabaya yang baru saja selesai menjalani penugasan stase di Divisi BTKV Departemen/KSM Ilmu Bedah FK Udayana/RSUP Sanglah Denpasar, Program Studi Ilmu Bedah merumahkan peserta didik yang saat itu sedang menjalani stase di Divisi BTKV (riwayat kontak) mulai 20-31 Maret 2020.

Hal tersebut dilakukan untuk menghindari penyebaran Virus Corona karena adanya riwayat melakukan kontak selama menjalani stase bersama-sama. Ditambah dengan adanya himbauan dan surat edaran dari Direktur RSUP Sanglah Denpasar Nomor KP.04.01/INT.XIV.2.1.1/0498/2020 tentang pelayanan di RSUP Sanglah untuk menghindari meluasnya penyebaran infeksi COVID-19. ${ }^{8}$

Selain itu koordinator Program Studi iImu Bedah menanggapi dan melaksanakan surat edaran RSUP Sanglah melalui surai pengantar Nomor 226/UN14.2.2.V.12/PD/2020 untuk membatasi kegiatan yang bersifat mengumpulkan orang (seminar, workshop, atau pelatihan), melakukan penundaan penerimaan siswa praktek dari institusi pendidikan, dan mengatur pegawai yang dapat bekerja dari rumah. ${ }^{9}$ 
Berdasarkan Surat Edaran RSUP Sanglah memperhatikan kurikulum PPDS dan

Denpasar

YR.01.01/INT.XIV.1.1.1/037/2020 tentang

Penundaan Operasi Elektif menginstruksikan bahwa ${ }^{10}$ :

1. Tindakan operasi elektif ditunda untuk sementara waktu sampai ada pemberitahuan lebih lanjut.

2. Tindakan operasi emergency / life saving tetap dilakukan dengan penggunaan APD standar untuk semua tim operasi.

Staf pengajar dan peserta didik mengikuti instruksi diatas oleh karena menyadari dan paham dengan risikonya. Penyesuaian protokol saat ini harus dilakukan ketika bukti ilmiah baru dan kebijakan rumah sakit dibuat. Saat dunia berjuang untuk pertempuran melawan COVID-19, peran tenaga pengajar dan peserta didik PPDS-1 Ilmu Bedah khususnya di Indonesia sangat besar dan sangat penting untuk manajeman tata laksana pasien di bidang bedah. Indonesia mempunyai situasi yang berbeda dengan negara lain, pada saat krisis seperti ini program studi harus bertindak secara ilmiah dan kreatif.

Kolegium Ilmu Bedah Indonesia (KIBI) mengadakan acara dengan agenda evaluasi COVID-19 pada Prodi Bedah yang dibuka oleh DR. Dr. Ibrahim Labeda, Sp.B-K)BD, FCSI. Disampaikan data sebaran yang diterima dari para Ketua Prodi diseluruh Indonesia bahwa Pendidikan Bedah sangat ideal, perbandingan dosen dan PPDS saat ini adalah 2:1. Selain itu yang penting adalah kerelaan para staf untuk memberikan kesempatan seluas luasnya kepada PPDS untuk mendapatkan waktu bimbingan mencapai kompetensi bedah. Kolegium menghimbau agar semua PPDS yang ada di rumah sakit jejaring dikembalikan ke institusi asal untuk perlindungan terhadap wabah ini. Koordinator Program Studi perlu pembelajaran dengan sistem online. Terdapat beberapa Program Studi Bedah dalam pemantauan akibat COVID- 19, yaitu:

1. Staf ada 5 orang (FK UGM - 1, FK UNUD - 3, FK UNSRAT - 1).

2. PPDS (3 orang pemantauan dari FK UNHAS - 2 dan FK UGM 1).

3. PPDS FK UNUD (8 orang) yang dikarantina saat ini sudah negative.

4. PPDS FK UNSRAT (3 orang, 1 kategori ODP), 1 masih istirahat.

5. Sebagai doa, semoga semua tidak terinfeksi COVID-19, dan agar wabah segera berakhir. Mari cegah dengan ilmu dan iman (prevention is the best medicine).

Adapun hasil pembahasan zoom meeting yang diadakan oleh Kolegium Ilmu Bedah Indonesia, diantaranya:

1. Kalimat hand sanitizer agar diganti hand washing dengan sabun, karena sabun megandung alkali.

2. Ruangan Operasi, Poli, dan UGD agar diawasi dengan cermat.

3. Tidak semua pasien yang menjalani operasi dilakukan screening dari COVID19 di Indonesia. Operasi elektif dapat dikerjakan setelah selesai COVID-19. Konsul jarak jauh dapat melalui WhatsApp. Operasi laparaskopi belum boleh dikerjakan selama wabah karena berisiko tinggi.

4. Semua PPDS yang ada di Rumah Sakit jejaring agar dikembalikan untuk perlindungan terhadap wabah ini. Koordinator Program Studi perlu memperhatikan kurikulum PPDS.

5. Berkaitan dengan COVID-19, agar sedikit PPDS yang kontak dengan pasien dan PPDS harus selamat di kondisi wabah.

6. Koordinator Program Studi (KPS) perlu memberikan kelengkapan APD, 
pengaturan jadwal jaga di poliklinik dan UGD yang diseling dengan libur. Ujian stase dilakukan dengan sistem online.

7. PPDS merupakan generasi penerus dan memerlukan istirahat yang cukup saat harus jaga. Triage seharusnya dilakukan di luar UGD, kerena di dalam UGD menggunakan AC sentral. Pasien dalam pemantauan perlu dilakukan triage, dipilah-pilah, dan jangan di campur aduk.

8. Bersumber pada penanganan SARS dan MERS dapat dibuat pedoman singkat selama wabah COVID-19.

Untuk persiapan pelaksanaan Ujian Nasional yang diadakan oleh KIBI, ditayangkan skenario Ujian Nasional KIBI periode Juni 2020 oleh dr. Rosadi Seswandhana, Sp.B, SpBP-RE(K). Atas dasar dilarangnya berkumpul banyak orang, maka diusulkan untuk Ujian Nasional Juni 2020 dilaksanakan secara online untuk Ujian Tulis dan Ujian Profesi. Ujian OSCA sulit untuk dilaksanakan, maka akan diundur di periode berikutnya karena tidak mempengaruhi masa studi.

Secara teknis akan dibahas untuk pelaksanaan ujian profesi secara online dan dalam masa darurat serta sesuai himbauan Menteri Pendidikan dan Kebudayaan, bahwa ujian dihilangkan dengan adanya wabah ini. KIBI masih menunggu keputusan dari MKKI. Adapun perkembangan dari hasil diskusi tersebut adalah:

1. Ujian Profesi tetap dilaksanakan secara online.

2. Akan dihitung biaya penyelenggaraan dengan pemakaian zoom.

3. Model online, untuk pembelajaran ujian secara online dan diusulkan tiap senter berlangganan zoom.

4. KPS harus jujur saat mendaftarkan peserta ujian profesi dan tidak boleh mengajukan peserta yang belum memenuhi persyaratan, diikutsertakan dalam ujian nasional.

5. Persiapan pelaksanaan ujian online akan dijalankan di minggu minggu ke depan.

6. Penambahan peserta, secara teknis sukar tetapi akan dipikirkan lagi.

7. Mengenai biaya UNAS mengingat secara online masih akan dihitung.

8. Agar ditinjau kembali sponsor dengan perusahaan asing perlu dipertimbangkan.

9. KIBI akan survey ke 16 Program Studi mengenai kebijakan masing-masing, tentang SPP (Sumbangan Pembinaan Pendidikan), dan masa studi.

10. Evaluasi komisi ujian dan kursus-kursus, KIBI merencanakan pertemuan pada minggu ke depan.

Berdasarkan beberapa instruksi di atas dapat diambil kesimpulan bahwa seluruh peserta Program Pendidikan Dokter Spesialis (PPDS) terutama bagian Ilmu Bedah dapat menyesuaikan dan mengikuti seluruh aturan yang berlaku, yaitu menjalankan pola hidup sehat dan mengutamakan kebersihan diri sendiri, menggunakan APD lengkap dalam memberikan pelayanan kesehatan, mengubah pembelajaran melalui tatap muka menjadi pembelajaran dari rumah (online), menjalankan pola hidup sehat dan mengutamakan kebersihan, serta mengurangi penugasan residen untuk stase luar hingga kondisi dan situasi dinyatakan aman untuk dilakukan kegiatan pembelajaran seperti semula.

\section{DAFTAR PUSTAKA}

1. Direktorat Jenderal Pencegahan dan Pengendalian Penyakit. Pedoman Pencegahan dan Pengendalian Coronavirus Disease (COVID-19) Revisi ke-4. Jakarta: Kementerian Kesehatan Republik Indonesia; 2020. 
2. Kementerian Kesehatan Republik Indonesia. COVID-19: Situasi kasus Indonesia. [serial online]. 30 Maret 2020 [diakses 30 Maret 2020]. Diunduh dari: https://infeksiemerging.kemkes.go.id/.

3. Rektor Universitas Udayana. Instruksi Rektor Universitas Udayana Nomor I Tahun 2020 Tentang Pencegahan Perkembangan dan Penyebaran Corona Virus Disease (COVID-19) di Universitas Udayana. Jimbaran: Universitas Udayana; 2020.

4. Kementerian Kesehatan Republik Indonesia. Surat Edaran Menteri Kesehatan RI Nomor HK.02.01/MENKES/199/2020 Tentang Komunikasi Penanganan Corona Virus Disease (COVID-19). Jakarta: Kementerian Kesehatan Republik Indonesia; 2020.

5. Universitas Udayana. Infrastruktur Memadai, Unud Siap Terapkan Pembelajaran Online Antisipasi Penyebaran Corona Virus. [serial online] 17 Maret 2020 [diakses 30 Maret 2020]. Diunduh dari: https://www.unud.ac.id/in/headline3300Infrastruktur-Memadai-Unud-SiapTerapkan-Pembelajaran-OnlineAntisipasi-Penyebaran-CoronaVirus.html.

6. Rektor Universitas Udayana. Surat Edaran Kementerian Pendidikan dan Kebudayaan Universitas Udayana Nomor B/1/UN14/SE/2020 tentang Pencegahan Perkembangan dan Penyebaran Corona
Virus Disease (COVID-19) di Universitas Udayana. Jimbaran: Universitas Udayana; 2020.

7. Dekan Fakultas Kedokteran Universitas Udayana. Intruksi Dekan Fakultas Kedokteran Universitas Udayana Nomor B/25/UN14.2.2/PK/01.03/2020 yang ditujukan untuk para Koordinator Program Studi Pendidikan Dokter Spesialis dan Para Ketua Departemen di RSUP Sanglah Denpasar. Denpasar: Fakultas Kedokteran Universitas Udayana; 2020.

8. Direktur Utama Rumah Sakit Umum Pusat Snglah. Surat Edaran Kementerian Kesehatan RI Direktorat Jenderal Pelayanan Kesehatan Rumah Sakit Umum Pusat Sanglah Denpasar Nomor KP.04.01/INT.XIV.2.1.1/0498/2020 tentang Pelayanan di RSUP Sanglah. Denpasar: Rumah Sakit Umum Pusat Sanglah Denpasar; 2020.

9. Koordinator Program Studi Ilmu Bedah. Surat Pengantar Nomor 226/UN14.2.2.V.12/PD/2020. Denpasar: Program Studi Ilmu Bedah; 2020.

10. Direktur Pelayanan Medik, Keperawatan, dan Penunjang Rumah Sakit Umum Pusat Sanglah Denpasar. Surat Edaran Kementerian Kesehatan RI Direktorat Jenderal Pelayanan Kesehatan Rumah Sakit Umum Pusat Sanglah Denpasar Nomor YR.01.01/INT.XIV.1.1.1/037/2020 Tentang Penundaan Operasi Elektif. Denpasar: Rumah Sakit Umum Pusat Sanglah Denpasar; 2020. 